\title{
Assortative mating for Cigarette Smoking and for Alcohol Consumption in Female Australian Twins and their Spouses
}

\author{
A. Agrawal · A. C. Heath · J. D. Grant • \\ M. L. Pergadia · K. K. Bucholz · P. A. F. Madden • \\ D. J. Statham · N. G. Martin
}

Published online: 23 September 2006

(C) Springer Science+Business Media, Inc. 2006

\section{Erratum to: Behav Genet \\ DOI: 10.1007/s10519-006-9081-8}

Due to a typesetting error, in the article "Assortative Mating for Cigarette Smoking and for Alcohol Consumption in Female Australian Twins and their
Spouses" by Arpana Agrawal, Andrew C. Heath, Julia D. Grant, Michele L. Pergadia, Dixie J. Statham, Kathleen K. Bucholz, Nicholas G. Martin and Pamela A. F. Madden, Michael Stallings was not given credit for editing.

Springer regrets the error. 